\title{
Kinetic Determination of 2,7-Dihydroxynaphthalene by Using Belousov-Zhabotinsky Electrochemical Oscillation System
}

\author{
Waqar Uddin \\ Office of Research Innovation and Commercialization, Bahria University, Karachi Campus, Pakistan \\ E-mail: vickyfuelche@yahoo.com
}

Received: 27 September 2021 / Accepted: 9 November 2021 / Published: 6 December 2021

\begin{abstract}
A new analytical approach for the kinetic determination of 2,7-dihydroxynapthalene (2,7-DHN) by perturbation effect with its narrow concentration range on Belousov-Zhabotinsky (BZ) oscillator catalyzed by tetra-aza-macrocyclic copper complex catalyst $\left([\mathrm{CuL}]\left(\mathrm{ClO}_{4}\right)_{2}\right.$ was reported in this paper. The Ligand " $\mathrm{L}$ " in this complex is 5,7,7,12,14,14-hexemethyl-1,4,8,11-tetraazacyclotetradeca-4,11diene. Perturbation experiments were performed after optimizing the oscillation parameters which indicates that the change in the oscillation amplitude $(\Delta \mathrm{A})$ is directly proportional to the concentration of 2,7-DHN added in the range of $4.50 \times 10^{-4} \mathrm{~mol} \mathrm{~L}^{-1}$ to $1.80 \times 10^{-3} \mathrm{~mol} \mathrm{~L}^{-1}$ with the correlation coefficient of 0.98 . The calculated relative standard deviation (RSD) from the 6 measurements obtained by the injection of $5.00 \times 10^{-3} \mathrm{~mol} \mathrm{~L}^{-1}$ is $1.90 \%$. The lower limit of detection (LOD) is $2.10 \times 10^{-4} \mathrm{~mol}$ $\mathrm{L}^{-1}$. Factors that influence the oscillation system were studied. A reaction perturbation mechanism was proposed based on a novel FKN model.
\end{abstract}

Keywords: Oscillating System; Perturbation; Dihydroxynapthalene; Macrocyclic Catalyst; BelousovZhabotinsky

\section{$\underline{\text { FULL TEXT }}$}

(C) 2022 The Authors. Published by ESG (www.electrochemsci.org). This article is an open access article distributed under the terms and conditions of the Creative Commons Attribution license (http://creativecommons.org/licenses/by/4.0/). 